\title{
Food Poverty and Youth Work - A Community Response
}

Jon Ord,

Plymouth Marjon University, England

Annie Monks,

Plymouth Marjon University, England

\begin{abstract}
This article discusses the findings of a small-scale study investigating the impact of food poverty on youth work in community based open access settings. It documents the growing impact of food poverty on the role of youth work in deprived communities and explores the role youth workers play in addressing it. Firstly this 'community response' addresses the issue of food poverty in localities where it arises. However, it not only meets basic needs, but it also helps build social capital by enacting important social relationships associated with food by 'eating together'. Such responses also have the potential to combat stigma and abjection through the creation of critical consciousness and political education. The research also highlights the need for greater coordination of this response and for youth centres to be less isolated from other services. Finally, the legacy of food policy within youth work is highlighted, previously dominated by a focus on healthy eating since Every Child Matters (2003). Post austerity, for many communities the concern is simply 'eating'!
\end{abstract}

\section{Key words}

Young people, social capital, critical consciousness, informal education, healthy eating policy,

\section{Food Poverty}

Poverty levels in the United Kingdom (UK) can only be characterised as shocking. Whilst the UK is the fifth richest country in the world (IMF, 2017) 14 million people are living in poverty, 1.9 million of whom are pensioners, 4.1 million are children and over 8 million are of working age (JRF, 2017, UN, 2019). Oxfam (2018) suggests overall one in five adults in the UK live below the poverty line. This situation is particularly harsh for children and young people with more than one in four affected by poverty (CPAG, 2019), nearly half of whom live in working households. Child poverty is both material, with children not having adequate food, clothing and heating in their homes, as well as societal, as poverty affects children's education, aspirations and future life chances (House of Lords, 2016).

In 2010 there was cross party support for the Child Poverty Act with its commitment to eradicate child poverty (CPAG, 2020). There were also assurances from the then 
prime minister David Cameron that he would: 'transform the life chances of the poorest in our country and offer every child who has had a difficult start the promise of a brighter future' (2016). However, the relentless commitment to austerity policies has simply exacerbated poverty levels, as the UN rapporteur points out:

The bottom line is that much of the glue that has held British society together since the Second World War has been deliberately removed and replaced with a harsh and uncaring ethos. A booming economy, high employment and a budget surplus have not reversed austerity, a policy pursued more as an ideological than an economic agenda.

(United Nations, 2019)

As a direct result of these austerity policies, forecasts from the Institute for Fiscal Studies suggest that child poverty will continue to rise until at least 2022, rising from $27.5 \%$ in $2014-15$ to $30.3 \%$ in $2021-22$ (IFS, 2017). This is an increase of more than a million children living in poverty.

Food poverty is a significant and growing aspect of this overall increase in poverty. In 2013, the Centre for Business and Economic Research suggested that 4.7 million people were living in food poverty (CEBR, 2013). Oxfam (2018) estimate that over two million people are malnourished in the UK, with another three million at risk of becoming malnourished. 17 per cent of the adult population are anxious about whether their food supply will last until they have enough money to buy more (Caplan, 2017). Scientists at the Medical Research Council have warned that extent of food poverty is a public health emergency (Taylor-Robinson et al, 2013). This differentially affects the most vulnerable groups in the UK:

People with disabilities, people receiving out-of-work benefits and lone parents. The severity and chronicity of food insecurity observed in this population is a concern for malnutrition and poor diet quality, which may be compounded by poor mental health, and/or lead to further declines in physical and mental health. 
Food banks have been a widespread and growing response to food poverty (O'Dowd, 2013; Lambie-Mumford and Dowler, 2014, Lambie-Mumford, 2019). Prior to the implementation of austerity policies in the UK, food banks were largely unknown. However, by 2015 over a million individuals were accessing food banks to support themselves and their families (Garthwaite, 2016). The Trussell Trust (2019), which is currently the largest food bank association in the UK, provided 1,332,952 emergency food parcels to people in $2017 / 18$. This was delivered from their 425 food banks across the country, with 67,506 food parcels for children alone. This represents a significant increase from 2013/14 when they provided 913,138 food parcels (The Trussell Trust, 2019). This exponential growth has led some to question the sustainability of food banks and question whether we 'are reaching a point where many food banks are struggling to meet demand, people will be denied service, provision is being rationed, and we are getting closer to a point where some food banks could fail' (lafrati, 2016: 307). Despite this the government have struggled to articulate the reasons behind the growth in food bank use across the nation. They have also failed to admit the link between the use of food banks and the restructuring of welfare benefits (Garthwaite, 2016). A senior government minister, Michael Gove, caused outrage when he suggested people's inability to buy food was merely due to their own financial mismanagement (O'Hara 2014), which further provoked an 'Open letter to Prime Minister David Cameron' on food poverty in the UK, published in The Lancet, (Ashton et al, 2014), with 170 signatories.

The primary reason people turn to food banks is unsurprisingly, according to Caplan (2017), a lack of income, as quite simply when essential bills and rent are paid there is little left to buy food. Caplan maintains that overall eight per cent of adults are eating less than they ought, going hungry or not eating for whole days at a time. Many of these adults are 'not prioritising their own needs, they sacrifice personal necessities in favour of spending on children' (Main and Bradshaw, 2016: 1). Women are particularly at risk of going without food, with ten per cent of female led households being below the poverty line, compared to six per cent of male led households (Food Standards Agency, cited in Caplan 2017). Women were also more at risk in homes with children, as they would often sacrifice their own meals in order for their children to eat. The Trussell Trust (2014) maintain that one in five mums were 'skipping meals to feed their children'. 
Other reasons why people are forced into food poverty are the specific benefit changes introduced by the Conservative government, most notably the introduction of Universal Credit (O'Hara, 2014; The Trussell Trust, 2019) and its associated delays in benefits, resulting debt and the introduction of sanctions. For example, the Trussell Trust (2013, cited in O'Hara, 2014: 29) found that almost 30 per cent of food bank vouchers were necessitated by benefit delays, 18.5 per cent by low incomes and nearly 15 per cent due to benefit changes. Overall these three factors accounted for nearly two thirds of all food bank use; other factors included homelessness, domestic violence, sickness and unemployment.

Despite the variety of reasons for food poverty Lambie-Mumford $(2017,2019)$ describes how food banks have become an established feature of modern Britain, having been widely documented since their sudden and dramatic arrival. There are now increasingly elaborate criteria governing accessibility, qualifying criteria, referrals and thresholds. They are widely discussed in the media and in Parliament, for example House of Lords, 2016. O'Hara (2014: 32) argues that 'a creeping normalisation of food poverty was taking place and that the state was abdicating any responsibility for it'. Illustrative of this state of affairs is that there are still no definitive figures on the extent of food poverty, the number of food banks or the total number of people accessing food parcels in the UK.

\section{Youth Work}

Youth work is an informal educational process which young people access voluntarily and it is their choice to engage with the youth worker (Jeffs and Smith 2005). This encounter commonly takes place in 'open access' community contexts in either designated youth clubs and projects, or on the streets and in parks through detached youth work. Youth work 'starts where young people are' (Davies 2015: 100), 'connect[ing]' with the person, with what they know, how they feel, what they want from the encounter' (Davies, 2015:106). Youth workers commonly work within the 11-25 age range, (NYA 2020) although this is sometimes prioritised to 13-19 (DfES, 2002). 
Youth work focuses on personal and social development - the skills and attributes of young people - rather than to 'fix a problem'. It is an educational process that engages with young people in a curriculum that deepens a young person's understanding of themselves, their community and the world in which they live and supports them to proactively bring about positive changes.

(National Youth Agency, 2020)

Youth work has broad educational aims. It does not operate according to a set curriculum or lesson plan (Ord 2016). Youth workers often work reactively responding to what occurs in the dynamic social environment, where young people meet, engage and chat - 'going with the flow' of the conversation (Jeffs and Smith 2011), intervening appropriately to stimulate thoughts or challenge preconceptions. They can also work proactively - planning educational inputs to stimulate awareness or educate the young people on a particular theme to:

promote young people's personal and social development and enable them to have a voice, influence and place in their communities and society as a whole. It builds resilience and character and gives young people the confidence and life skills they need to live, learn, work and achieve.

(National Youth Agency, 2020)

Promoting health and well-being has always been an essential part of the informal educational process of youth work and its curriculum framework may well encompass the aim of increasing young people's awareness of food and healthy eating. However, as we shall see significant changes were made in the early $21 \mathrm{st}$ century under the New Labour youth work policy agenda, which continue to influence youth work, but are in stark contrast to the identified needs of young people in food poverty.

\section{Youth Work Policy and Healthy Eating}

In the 1980s the Thatcher Government made an unsuccessful attempt to impose an outcomes-based practice on youth work (Davies, 1999). Prior to this youth work organisations had by and large set their own priorities, responding to the identified needs of the young people they were working with. This changed however with the 
arrival of New Labour and the publication of 'Transforming Youth Work' (DfES, 2002). As a result, youth work organisations were now expected to establish 'programmes which engage with contemporary social issues such as health...' (DfES, 2002: 27), a significant number of which must 'offer accreditation for learning' (DfES, 2002: 22).

This shift to programme and outcome focused practice was enhanced further by the arrival of the Every Child Matters Green Paper a year later (DfES, 2003). This outlined the five outcomes that youth workers (alongside other professionals) should aim to achieve (being healthy, stay safe, enjoy and achieve, make a positive contribution, and achieve economic well-being). Most notable of these outcomes in the context of this article is 'being healthy'. The Every Child Matters Green Paper was met with cross party support and the significant changes to local children's and youth services were enacted in the Children's Act 2004 (Smith, 2005). The following year saw the publication of Youth Matters (DfES, 2005). Whilst Every Child Matters related to all services that worked with children and young people, from formal education to social services (which did nominally include youth work), the purpose of Youth Matters was to identify how youth work, particularly statutory youth services, should specifically respond to the newly identified priorities of Every Child Matters. Youth Matters cemented the role of youth work within the broader integrated world of Every Child Matters. This resulted in a move away from relationship-based practice which responded to the expressed concerns of young people to a delivery-based practice which prioritised externally imposed outcomes and priorities (Smith 2002).

As a direct response to this policy shift youth workers started delivering programmed work which responded to these particular policy priorities. As a result, healthy eating programmes became very popular amongst youth workers and these still appear to be current throughout the UK. For example, Rogers (2013) produced an online guide to youth work sessions on: 'How to Encourage Healthy Eating', suggesting

Eating a healthy, balanced diet is important for everyone. This means eating a wide range of foods, including the occasional treat, and balancing this with the amount of exercise done each day. To help open up discussions and start to explore healthy eating, here are a few tried and tested activities: 
In Scotland, a health partnership in North Glasgow produced 'The Youth Food Guidelines and Healthy Eating Toolkit' (North Glasgow, 2014). It is based on research with young people and youth workers and 'the guidelines have been developed to support healthy eating in youth clubs (North Glasgow, 2014: 2). The research indicated that ' $60 \%$ of youth workers think there is definitely a need for healthy eating guidelines, and $100 \%$ think these will affect the young people they work with in a positive way (ibid). Healthy eating appears to be embedded in youth work practice in this area where ' $50 \%$ of youth clubs have someone trained in food hygiene... $23 \%$ have someone trained in nutrition....and just over $1 / 2$ of youth clubs do some healthy eating activities at the moment' (ibid).

In Wales a handbook was produced to facilitate the ability of youth workers to deliver healthy eating programmes in youth work settings. This was part of the 'Library of Good Practice - Method and Resource Handbooks for Youth Work in Wales'. Its purpose was to: 'consider a number of key public health priority areas with respect to young people aged 11-25' (CWYVS, 2014: 4). The handbook suggested that

\begin{abstract}
Youth Work practitioners are ideally placed to raise awareness and deliver health related information and resources to young people. This Handbook aims to help youth workers deliver a variety of health-related activities to young people in youth work settings
\end{abstract}

(CWYVS, 2014:14)

In the context of this article, it is of note that this healthy eating policy agenda has not been updated or superseded during the food poverty crisis that has befallen Britain. The crisis will no doubt be affecting many of the communities to which these healthy eating polices are directed. This research addresses this policy vacuum in the area of young people and food poverty.

\title{
Introduction to the research study
}

The research is a small-scale study undertaken in three open access youth work organisations in a deprived urban setting in the South West of England. Two of the organisations were part of the local authority youth service and one was located in the 
voluntary sector. The research aimed to understand how food poverty impacted on youth work. In particular, it was concerned with the youth workers' understanding and awareness of food poverty and whether, and how, youth workers were responding to issues of food poverty. A series of semi structured interviews were undertaken over a 6-month period with a range of youth workers in each of the three organisations. Although convenience sampling and snowballing were utilised, it was ensured that the respondents ranged in age as well as levels of qualifications and experience. Respondents were however excluded if they did not have a minimum of 12 months experience at the particular setting to ensure a sufficient level of understanding of the local community and the youth centre's role within it.

This research was undertaken in 2019, prior to the Covid 19 crisis. The issues discussed in this article have unquestionably been exacerbated by the pandemic. For example, a Food Foundation report concluded that the number of adults who were food insecure quadrupled during the pandemic (Loopstra, 2020). The Trussell Trust also identified a significant increase in the use of their food banks seeing an ' $89 \%$ increase in need for emergency food parcels during April 2020 compared to the same month last year, including a 107\% rise in parcels given to children' (Trussell Trust, 2020). UNICEF have also announced that, for the first time in their 70 year history, they will be distributing food to children in the UK (UNICEF, 2020). Hence the issues discussed and the conclusions drawn here are undoubtedly even more pressing today.

\section{Background to the research}

The study was undertaken within a local authority which is ranked 64 out of 316 local authorities in England on the Index of Multiple Deprivation (IMD) rankings (LGA, 2019). Like most local authorities however this overall statistic masks a range of deprivation within it. To illustrate, deprivation at a local level central government and the Office for National Statistics (ONS) utilises a geospatial statistical unit referred to as Lower Layer Super Output Area (LSOA). LSOAs have a minimum population of 1000 and a mean population of 1,500 . The LSOA in which youth centre one in this study is located is ranked 2,491 out of 32,844 in England and is therefore in the top $10 \%$ most deprived neighbourhoods in England (GOV.UK, 2019). The LSOA in which youth centre two is located is ranked 4,257 in England and is therefore in the 
top $20 \%$ most deprived neighbourhoods in England (ibid) and the LSOA in which youth centre three is located is ranked 8,646 in England and is therefore in the top $30 \%$ most deprived (ibid). This latter local authority as a whole is very significantly deprived, because its least deprived LSOA is still within the $40 \%$ most deprived in the country. Details of the age, gender and ethnicity of the participants of the youth centres, as well as the average number of participants at the youth centres per evening, is given Table 1.

Table 1 Age, gender and ethnicity of the young people attending the youth centres

\begin{tabular}{|l|l|l|l|l|l|l|l|}
\hline & $\begin{array}{l}\text { Age } \\
\text { range }\end{array}$ & $\begin{array}{l}\text { Average } \\
\text { attendance }\end{array}$ & $\begin{array}{l}\text { Average } \\
\text { age }\end{array}$ & Female & Male & White & BAME \\
\hline $\begin{array}{l}\text { Youth } \\
\text { centre one }\end{array}$ & $10-18$ & 60 & 14 & $40 \%$ & $60 \%$ & $92 \%$ & $8 \%$ \\
\hline $\begin{array}{l}\text { Youth } \\
\text { centre two }\end{array}$ & $10-19$ & 45 & 15 & $50 \%$ & $50 \%$ & $94 \%$ & $6 \%$ \\
\hline $\begin{array}{l}\text { Youth } \\
\text { centre three }\end{array}$ & $11-16$ & 40 & 14 & $38 \%$ & $62 \%$ & $95 \%$ & $5 \%$ \\
\hline
\end{tabular}

As table 1 shows, the centres were well attended, with an average attendance across the three centres of just under 50 . Each had a similar age range of around 10-19, with an average age of 14 or 15 . There were slightly more boys in attendance at the centres, but each had a significant proportion of girls. The youth centres were attended by young people who were predominantly white. There were no discernible differences observed within the research process along the parameters of gender, age or ethnicity, although it should be noted that the primary focus of the inquiry was the responses of the youth workers.

\section{Findings}

It was immediately apparent that the youth workers at all three youth centres were concerned about food poverty in the communities within which the centres are located. They were also acutely aware that this was having a direct impact on the young people who attended their centres. The response that the centres were unanimously adopting was to ensure they fed their young people and each centre regularly provided food in their open access youth work sessions. As one youth worker at youth centre three made clear: 'I provide food in all my sessions'. In some instances, the feeding of young people was almost on an industrial scale, for 
example at youth centre one they were feeding up to 60 young people across three sessions in one evening. Another youth worker estimated that around $50 \%$ of the young people attending the project lived in families using food bank vouchers.

The food offered was usually simple yet effective, 'filling a hole' - literally trying to fill the young people's empty stomachs; it was often cheap but where possible nutritious, such as toast, beans and spreads.

We go through about, anywhere, from like three to five loaves of bread, couple of tins of beans... we can get the big industrial tins... That's in one session.

(Youth worker at youth centre two)

These interventions to feed the young people who attended the youth centres occurred despite there being no designated budget for food. The youth workers invariably 'found a way' to ensure food was provided, given it was deemed to be an absolute necessity. As a youth worker from youth centre two said the: '[food] just comes out of the centre's money. That youth centre, perhaps because it was based in the voluntary sector did manage to establish links to some of the local supermarkets which enabled it to access cheap or even free food that was close to its sell by date. As one youth worker explained:

I mean we always manage to get funding for food. When we lost our funding a couple of years back... I remember for a short period of time we weren't able to do food for young people because we just didn't have the money. But we've always kind of managed to find a way out of it. I remember we got donated a load of food by Aldi or Lidl... And then we got a small food budget from the co-op.

(Youth worker at youth centre one)

The scale of the problem, however, was even beginning to take some of the youth workers by surprise. For example a youth worker from youth centre one said: 'it's a massive issue for young people at the moment and it affects them greatly... 'We've never seen it like this.... Before, you know, [you] might get the odd one or two to you. 
But this is different'. All the youth workers involved in this research unanimously rose to the challenge presented by the young people's food poverty. One way or another they managed to ensure that the young people who attended their centres were at least a little less hungry.

\section{Food poverty: youth work as a community response?}

The youth work interventions on food poverty identified in this research are a community-based response. As Clarke (1973) reminds us however, notions of community extend beyond mere geographical location to aspects of social activity and shared interest, linking to aspects of sentiment and belonging, as well as reflecting key social divisions and structures. The youth work response to food poverty relates to each of these different aspects of community.

\section{A local response}

The youth work response to food poverty is most immediately apparent in its attempts to address what Pemberton et al (2017) refer to as the 'endless pressure' of food poverty, as youth workers attempt to meet the pressing physical needs of hunger in the geographical communities of young people within which the youth centres are located. This role that youth centres are undertaking in responding to food poverty is however a hitherto undocumented phenomenon. There are other local community-based responses. For example, the role of Breakfast Clubs is quite well established within schools, where it has become increasingly recognised as having

moved from being seen as part of structural, state-driven approaches to poverty and social inclusion to feeding initiatives plugging gaps in increasingly lean state provision. (Lambie-Mumford and Sims, 2018: 246)

Breakfast Clubs have thus moved from a provision originally established to ease the transition back to work for parents, to primarily one of responding to food poverty.

The role of Holiday Clubs in meeting the food poverty needs of children during school holidays has also been widely acknowledged (Machin, 2016; APPG, 2017; Long et al, 2018; Lambie-Mumford and Sims, 2018). However, as the Feeding Britain Report shows 'we are still only scratching the surface... [of] how children who eat little and badly over the holidays start to suffer in terms of educational 
development' (APPG, 2017: 2). The problem of holiday food poverty is more apparent because of the contrast between the provision of free school meals during term time and the lack of a statutory duty to feed children in the holidays. During the Covid 19 pandemic, this issue has been highlighted in a campaign given great voice by the footballer Marcus Rashford (Unison, 2020, Guardian, 2020). Whilst food poverty may be exacerbated during school holidays, our research also shows that young people are going hungry during term time. A number of youth workers emphasised how hungry young people are on school days. For example, a youth worker from youth centre two commented:

They come in starving after school, [so] we feed them. So, whenever we do after school clubs, we always have food. Yeah, because obviously, we know that kids are hungry

This previously undocumented role that youth centres are undertaking in addressing food poverty is noteworthy. However, its effectiveness may be enhanced if it was coordinated with other community-based provision. The two statutory youth centres in this study were operating independently from any of the services, agencies or other voluntary organisations in the locality. Some of the youth workers were aware of other organisations as one youth worker made clear: 'I think there's a lot of community organisations that are doing their utmost. The likes of Shekina, food banks and the local food community café (Youth centre two)'. But there were few attempts to make any connections with them, to see how they could support each other or coordinate their work.

This lack of coordination or integration with wider services is noteworthy in that the response to food poverty at the two local authority youth centres was not acknowledged by the youth service management or local councillors, so little wider coordination exists. The youth centres' response is laudable as an independent, 'bottom-up' grassroots, community response (Hudson et al, 1994) to a basic need, which the youth workers working with young people at the 'coal face' correctly identified and responded to appropriately. However, a more coordinated and appropriately supported response may well be more effective, not least in providing sustainability (lafrati, 2016). For example, the youth centres would no doubt benefit 
from forging links with Devon and Cornwall Food Action, an extensive network which: 'aim[s] to help people in food poverty by the redistribution of donated surplus produce' across the south west (DCFA, 2020).

The following quote is illustrative of the lost opportunity:

The local community know this is a community hub. I've had a couple of occasions where I had residents knocking on the door asking if I can direct them towards where they can get food parcels or where there is a food bank. And l've had to say go into town.

(Youth centre one)

The youth centre is clearly a valued and trusted place where people in food poverty feel able to seek advice. The potential exists therefore, to coordinate with other service providers and extend the services on offer at youth centres to respond more effectively to the issues of food poverty, beyond feeding young people in the open youth work settings. One of the benefits of the research was that the centres were beginning to think about how they could do things differently. For example, one centre acknowledged that coordination had: 'just never been explored [but] it would be a really good idea. If we were able to. If we could offer maybe a food bank that would be a brilliant idea and it is needed in the area yeah'. They acknowledged that there were difficulties with space, storage and staffing but that greater coordination and support across the food poverty network would be beneficial and that the strengths they have in the community could be built upon, for example perhaps they could be an outlet for food vouchers. The youth centre based in the voluntary sector was better coordinated as it was part of the Fare Share scheme allowing for the collection of surplus food every week from ASDA. It has subsequently forged links with a distribution network and the Food Bank. It has also recently assisted in distributing food vouchers in the local community.

\section{The 'social' aspect of food and food poverty}

Without diminishing the raw hunger in any way, considering other aspects of community opens up alternative ways of understanding the youth work response as Wills and O'Connell remind us: 'Food practices of children in poor and low-income 
households deserve special attention because food is fundamental - not only to health but also social life' (2018: 169). Youth workers in the study were explicitly aware that they were fulfilling more than basic physical needs and there was a wider social and community context to their response to food poverty. As one youth worker from centre three made clear, they were creating 'more of a sort of community food', going on to suggest that the meals offered opportunities to build togetherness and community spirit despite the desperate circumstances many of the young people find themselves in. The process of cooking together builds a sense of togetherness, as on youth worker described it: 'One of the big things we do is we cook with the young people, that's like a massive thing [it builds] quite a good community because...they will look after each other'. Food is also central to special events such as summer fairs, Christmas and Halloween; such times are used to bring people together around the issue of food. The community response to food poverty therefore not only meets the physical hunger in communities but helps build social capital.

As Batsleer (2016) argues, a different kind of relationship to those inevitably associated with food banks is possible in projects associated with community-based youth work. Food banks and food charities are almost by design: 'creating social abjection and division between the deserving and undeserving' (Batsleer, 2016: 189). Tyler (2013) developed the concept of 'social abjection' to describe the types of power relations which produce 'precariousness', suggesting that it is the processes of classification themselves which cause the social abjection. The food banks therefore, whilst set up to resolve the problem of food poverty, end up confirming and reinforcing the alienation and social exclusion. Community based projects on the contrary have the potential to recognise each other's vulnerability and 'in so doing point away from precaritisation, contempt, shame, hurt and derogation and towards another order of mutuality and care' (Batsleer, 2016: 200). 


\section{Food poverty, social structures and critical consciousness}

A number of the youth workers in this study acknowledged paradoxical feelings in responding to food poverty, on the one hand having strong moral obligations to address the needs of the young people in the best way they could, but, on the other hand, recognising the structural foundations of the problem which were not their responsibility. This is exemplified by one youth worker:

It's not our responsibility to feed them. That's the responsibility of central government, isn't it to make sure that everyone has access to enough money to buy food? But obviously, if a young person comes in and they're hungry, we're going to feed them... In youth work, our responsibility would be about trying to influence young people on how they can get out of that cycle of poverty... it's not really about kind of putting a plaster on everything...But obviously, in order to do that, we need to be working with reasonably healthy young people. So, they come in starving after school, we feed them...We always have food.

(Youth worker from youth centre three)

This paradox does, however, open up possibilities for the informal educator. It could be argued that the informal education processes, which youth workers ought to be engaging in with young people, are potentially undermined by the fact that many of the young people are too hungry to learn or engage in reflective conversations. However informal education and food poverty are not necessarily mutually exclusive, and one should be wary of setting them up as a false dichotomy (Siurala, et al, 2016). Boone et al (2019: 339) suggest that 'an understanding of the deeper structures within the economic, cultural and political injustices experienced by people in poverty' [can] contribute to processes in which a critical consciousness of people in poverty emerges'. Young people in food poverty are no exception and the political and economic circumstances that young people find themselves in provides ample 'grist to the mill' for the informal educator to engage in political education and have essential conversations about social justice. 
As Knight et al (2018) point out, how food poverty affects young people is complex and multi-layered. Food poverty does not just concern the quantity of food young people can access (whether they meet their basic recommended calorific intake) or the quality of the food they eat (ensuring the nutritional requirements are also met). Food (and inevitably food poverty) has a number of wider social ramifications Relationships are maintained and sustained through the provision of food and the sharing of meals. When this is absent or denied an important social and familial function is undermined. Those in food poverty are placed in an unenviable situation which produces significant stresses (Lambie-Mumford, 2017). The experience is demoralising and directly impacts on mental health and well-being more generally (O'Hara, 2014). It is all too easy for this process to be internalised, and for those in food poverty to feel stigmatised and experience low self-worth. This is exacerbated by the responsibilisation agenda of neoliberal discourse (Lambie- Mumford, 2019) which places the blame for 'perceived' failings squarely at the door of the individual (Levitas, 1988).

The provision of food at centres by youth workers opens up the possibility for important conversations with young people, not just about the physiological nutritional aspects of food, but also the social, emotional and psychological aspects as well as structural and political dimensions of food poverty. Indeed, the workers themselves were all too aware that the problems that they are dealing with are a consequence of cuts and government policy, as a youth worker from youth centre one pointed out: 'The cutting back on the services, what's happened to the benefit system, what's happened to support networks and if you look at it all, you've got the food poverty growing'. Caplan reminds the informal educator or the communitybased youth worker that:

By using food poverty and food aid as a prism, we may pose a series of questions about rights and entitlement; citizenship and the state; morality and ethics; the political economy of inequality, austerity and neoliberalism; government policies and their effects (including low wages and benefits); the self and the other. In short, about the way things are now and whether they could and should be different. Such an 'engaged anthropology' may thus play a part in the search for social justice. 
Though not easy skilled youth workers can therefore initiate conversations with young people about how understandably difficult it is for their families to sit down and eat meals together - like the ones the youth centre provides - appreciating how stressful their lives must be. They can explain that it is not their or their parents' fault, and that joblessness or low pay are products of factors beyond their control. Such exchanges are emotionally rich enabling a potential reframing of significant aspects of young people's lives. Realisations may well be generated which help inform a wider political education process, that can in time help elicit wider social change. There was however limited evidence of youth workers in this study taking advantages of these opportunities, although as a youth worker from youth centre two acknowledged: 'we could do more educational activities [related to the issues of food poverty]'.

The role of community based participatory approaches to exploring food poverty has been illustrated by a recent study undertaken by Wheeler (2018). She facilitated user-led, self-managed groups undertaking a number of visual art-based projects. These projects became an important medium of self-expression and group solidarity allowing members of marginalised communities to make sense of and legitimise their experiences. Food poverty and the participants' experiences of it were therefore transformed from something they passively endured, and which demoralised them, to something that they now expressed and articulated. Wheeler argues that, in so doing, such projects 'contribute to repositioning [those in food poverty] and [develops] the ability to resist stigma' (2018: 373). Whilst this is clearly not a solution to food poverty itself, it enables some of the debilitating aspects of food poverty to be mitigated. Similarly, Monforte (2020) points out how the act of volunteering itself can be seen as a generator of 'critical resilience', by bringing people together to create solidarity and resistance.

\section{Food poverty and healthy eating policy?}

The activities at the three youth centres to some extent continued the legacy of 'healthy eating'. For example, many of the participants discussed how they continue to get their young people involved in cooking activities and in food preparation. There 
was evidence from all three centres of attempts to create meals with their young people, 'get[ting] them all to do it from scratch... try[ing] to do proper meals ... curries, Bolognese, chilli con carné... we try to do substantial meals' (youth worker from youth centre one). Another youth worker from youth centre three pointed out how the serving of meals enabled the centre to bring people together saying ' $W e$ all like curries and potatoes'.

These kinds of activities well provide the kinds of 'life skills they [young people] need' (NYA, 2020), and healthy eating is still a policy priority. Learning about cooking seemed particularly important for many of these young people, given that some of the catering classes at the school the young people attended seemed inadequate and would not contribute to their learning about food. As a youth worker from centre two noted the classes seemed to be 'all microwave cooking and muffins ... [and] all processed food'. There is however, a potential paradox implicit within these kinds of healthy eating activities brought about by the reality of food poverty, because many of the young people live in households that cannot afford to eat these kinds of meals. For example, as one youth worker made clear:

One of the comments that always hits me is one of the young people said, "mum can't buy that". They just walk away as it's not something they'll get at home

(Youth worker at youth centre two)

In current policy discourse healthy eating has tended to focus on obesity and there is evidence that children from deprived areas are at a higher risk of being overweight in part due to the ease of fast food and young people not eating enough fruit and vegetables or healthy meals at home, not least because healthy food is more expensive (NHS, 2018). However, this study reveals an entirely different side to this policy discourse - malnutrition and young people who are underweight - as one youth worker from centre two noted:

We've got a few that are very tiny, and it is obvious that they are skinny, and they are underdeveloped, because of the malnutrition...we do get the young people that are very, very thin. 
This research indicates the stark shift which is yet to be acknowledged within youth work policy, as one youth worker put it: Before it was about making sure they had a healthy meal. Now it's 'are they eating?". It is imperative that youth work policy both recognises the irony in trying to educate young people in food poverty about 'healthy eating', as well as develop ways to respond to this crisis.

\section{Conclusion}

The extent of food poverty in the fifth richest country in the world is shameful and the resulting issues that youth workers are encountering are clearly symptoms of wider structural problems. These structural problems however require long term strategies such as those advocated within the Child Poverty Act (2010). Youth work food policy (which ostensibly still focuses on healthy eating) needs to acknowledge the profound shift that has occurred in communities - post austerity - which means that for many it is simply a question of having enough food to eat. The solutions to these problems cannot be provided by merely delivering youth work sessions focussing on healthy eating.

The significant role that youth work is playing to help mitigate some of the worst aspects of this crisis remains largely unacknowledged. Not only are youth workers meeting the physical needs of young people in food poverty, but they are also helping to meet wider social needs enabling young people to eat in a communal setting - sharing meals - and developing a sense of community and belonging as well as building social capital. Such settings are also an untapped resource for addressing issues of social justice through informal educational processes. Engaging young people in conversations which challenge the internalisation of their impoverished position, encouraging young people to realise their lives are structured into poverty and their situation is not a consequence of individual failing and moral deficiency but is a structural problem. Youth workers can, as well as meeting individuals' food poverty needs, use this crisis as an opportunity for political education.

Wider recognition and better resourcing, coordination and development of the role youth work would, however, certainly make it more effective. The youth centres in this study largely operated independently of the wider network of services and it is 
evident that they could benefit from support, not least in the supply of food. They themselves might also offer support to other services by developing themselves as community hubs. At present they remain a somewhat hidden but none the less vital resource.

\section{Reference List}

APPG (All-Party Parliamentary Group) on Hunger (2017). Feeding Hunger in the holidays: A feeding Britain report. [ https://feedingbritain.org/wpcontent/uploads/2019/01/Ending_Hunger_in_the_Holiday_Report_Dec_20173.pdf ] accessed 8 March 2020.

Ashton, J. R., Middleton, J. and Lang, T. (2014). Open letter to Prime Minister David Cameron on food poverty in the UK, LANCET 383(9929):1631.

Batsleer, J. (2016) Precarity, food and accompaniment in community and youth work, Ethnography and Education. 11(2): 189-203.

Boone, K.; Roets, G and Roose, R. (2019) Raising critical consciousness in the struggle against poverty: Breaking a culture of silence, Critical Social Policy 39(3): 434-454.

Cameron, D. (2016) Prime Minister's Speech on Life Chances', 11 January 2016 [ https://www.gov.uk/government/speeches/prime-ministers-speech-on-lifechances ] accessed $6^{\text {th }}$ Feb 2020.

Caplan, P. (2016) Big society or broken society?: Food banks in the UK, Anthropology Today 32(1): 5-9.

Caplan, P. (2017) Win-win? Food poverty, food aid and food surplus in the UK today, Anthropology Today 33(3): 17-22.

Centre for Business and Economic Research (2013) Trends in Food Poverty in the UK [https://cebr.com/reports/food-poverty/] accessed 6 Feb 2020.

Child Poverty Action Group (2019) Child poverty promise and Child Poverty Act. [ http://www.cpag.org.uk/content/child-poverty-promise-andchild-poverty-act] accessed 18th February 2019.

CPAG (2020) Child Poverty Action Group https://cpag.org.uk/recent-history-uk-childpoverty (accessed 11 $11^{\text {th }}$ December, 2020)

Clarke, D.B. (1973) The concept of community in Henderson, P. and Thomas, D.N. Readings in Community Work. London: George Allen and Unwin

Conservative Party (2015) Conservative Party Manifesto 2015, April 2015.

CWYVS (2012) Health and Well Being in Youth Work Method and Resource Handbook, [https://www.cwvys.org.uk/wp-content/uploads/2014/06/HBHealth-and-Wellbeing.pdf] accessed 10 Feb 2020.

Davies, B. (1999) From Thatcherism to New Labour: A History of the Youth Service in England, Volume 2. Leicester: Youth Work Press.

Davies, B. (2015) 'Youth Work: A Manifesto For Our Times - Revisited', Youth and Policy 114: 96-117.

DCFA, (2020) Devon and Cornwall Food Action https://devonandcornwallfoodaction.org/about-us/ (accessed 10 th August 2020)

DfES - Department for Education and Skills (2001) Transforming Youth Work: Developing youth work for young people. Nottingham: DFES. 
DfES - Department for Education and Skills (2002) Transforming Youth Work: 'Resourcing Excellent Youth Services. Nottingham: DFES.

DfES - Department for Education and Skills (2003) Every Child Matters. London: HMSO.

DfES - Department for Education and Skills (2005) Youth Matters. London: HMSO.

Loopstra, R. (2020) Food Foundation Report: Vulnerability to Food Insecurity since the COVID-19 Lockdown, https://foodfoundation.org.uk/wpcontent/uploads/2020/04/Report COVID19Foodlnsecurity-final.pdf (accessed 10th December, 2020)

Garthwaite, K. (2016) Hunger Pains: Life Inside Foodbank Britain. London: Policy Press.

Guardian (2020) Borisj Johnson and the second U-turn on Child Food Poverty https://www.theguardian.com/education/2020/nov/08/marcus-rashford-forcesboris-johnson-into-second-u-turn-on-child-food-poverty (accessed 12th December, 2020)

GOV.UK (2019) Lower Layer Super Output Area rankings in Englandhttp://dclgapps.communities.gov.uk/imd/iod index.html (accessed 5th August 2020)

House of Lords (2016) Causes of Child Poverty [file:///C:/Users/Jon\%20Ord/Downloads/LLN-2016-0036.pdf] accessed 6 Feb 2020.

Hudson, B.; Newman, T. and Drakeford, M. (1994) Developing a credit union - a community-based response to poverty, Critical Social Policy 14(41): 117-123.

lafrati, S. (2016) The sustainability of food bank provision: What happens when demand outstrips supply? The Journal of Poverty and Social Justice volume 24: 307-310

IMF (2017) International Monetary Fund: World Economic Outlook 2017, https://www.imf.org/en/Publications/WEO/Issues/2017/09/19/world-economicoutlook-october-2017 (accessed 12 ${ }^{\text {th }}$ December, 2020)

Institute of Fiscal Studies (2017) Living standards, poverty and inequality in the UK: 2016-17 to 2021-22 [https://www.ifs.org.uk/publications/8957] accessed on 6 Feb 2020.

Jeffs, T. and Smith, M.K. (2005) Informal Education, Conversation, Democracy and Learning, (3 $3^{\text {rd }}$ Edn.). Derby: Education Now.

Jeffs, T. and Smith, M. K. (2011). 'What is informal education?' the encyclopaedia of informal education. [http://infed.org/mobi/what-is-informal-education/] accessed 10 Feb 2020.

Knight, A.; O'Connell, R. and Brannen, J. (2018) 'Eating with Friends, Family or Not at All: Young People's Experiences of Food Poverty in the UK', Children and Society 32: 185-194.

Lambie-Mumford, H. (2017) Hungry Britain: The Rise of Food Charity. London: The Policy Press.

Lambie-Mumford, H. (2019) 'The growth of food banks in Britain and what they mean for social policy', Critical Social Policy 39(1): 3-22.

Lambie-Mumford, H. and Dowler, E. (2014) Rising use of "food aid" in the United Kingdom, British Food Journal 116(9): 1418-1425.

Lambie-Mumford, H. and Sims, L (2018) 'Feeding Hungry Children': The Growth of Charitable Breakfast Clubs and Holiday Hunger Projects in the UK', Children and Society 32(3): 244-254. 
Levitas, R. (1998) The Inclusive Society? Social Exclusion and New Labour, Basingstoke: Macmillan.

LGA (2019) Index of Multiple Deprivation Rankings:

https://lginform.local.gov.uk/reports/lgastandard?mod-metric=398\&mod-

area $=$ E06000026\&mod-group=AllUnitaryLalnCountry England\&modtype =namedComparisonGroup (accessed $4^{\text {th }}$ August 2020)

Long, M. A.; Stretesky, P. B.Graham, P. L.; Palmer, K J.; Steinbock, E. and Defeyter, M A. (2018) The impact of holiday clubs on household food insecurity - A pilot study, Health and Social Care in the Community 26(2): 261-269.

Loopstra, R. (2018) Rising food bank use in the UK: Sign of a new public health emergency?, Nutrition 43(1): 53-60.

Machin, R. J. (2016) Understanding holiday hunger, Journal of Poverty and Social Justice 24(3): 311-319.

Main, G. and Bradshaw, J. (2016) Child poverty in the UK: measures, prevalence and intra-household sharing, Critical Social Policy 36(1): 38-61.

Monforte, P. (2020) From compassion to critical resilience: Volunteering in the context of austerity, Sociological Review 68(1): 110-126.

NHS (2018) Statistics on obesity, Physical activity and diet - England, 2018, [https://digital.nhs.uk/data-and-information/publications/statistical/statistics-onobesity-physical-activity-and-diet/statistics-on-obesity-physical-activity-anddiet-england-2018] accessed 6 Jan 2020.

National Youth Agency (2020) What is Youth Work [https://nya.org.uk/careers-youthwork/what-is-youth-work/] accessed 7 Feb 2020.

North Glasgow (2014) Youth Food Guidelines and Healthy Eating Toolkit [https://www.ngcfi.org.uk/wp-content/uploads/2014/04/Youth-Food-ToolkitNorth-Glasgow.pdf] accessed 10 Feb 2020.

O'Dowd, A. (2013) Half a million people are using food banks in UK as food poverty grows. BMJ: British Medical Journal, 346(7911): 6.

O'Hara, M. (2014) Austerity Bites: A journey to the sharp end of cuts in the UK. Bristol: Policy Press.

Ord, J. (2016) Youth Work Process, Product and Practice: Creating an authentic curriculum in work with young people. Lyme Regis: Russell House

Oxfam (2018) Food Poverty in the UK. [https://policypractice.oxfam.org.uk/ourwork/inequality/food-poverty] accessed 14 January 2019.

Pemberton, S.; Fahmy, E. and Bell, K (2017) Endless Pressure: Life on a Low Income in Austere Times, Social Policy and Administration 51(7): 1156-1173.

Rogers, V. (2013) Youth Work Sessions: How to encourage healthy eating, [https://www.cypnow.co.uk/Features/article/youth-work-sessions-how-toencourage-healthy-eating] accessed 8 Feb 2020.

Siurala, L., Coussée, F., Suurpää, L. and Williamson, H (2016), 'Bridging youth work, but on whose terms?' in Siurala, L., Coussée, F., Suurpää, L. and Williamson, $\mathrm{H}$. (eds) The History of Youth Work in Europe: Autonomy through dependency - Histories of co-operation, conflict and innovation in youth work Volume 5, Strasborg: Council of Europe Publishing.

Smith, M. K. (2002) 'Transforming Youth Work - Resourcing excellent youth services. A critique', the informal education homepage, [http://infed.org/mobi/fromyouth-work-to-youth-development-the-new-government-framework-forenglish-youth-services/] accessed 10 Feb 2020. 
Smith, M. K. (2005) 'Youth Matters - The Green Paper for Youth 2005', the encyclopaedia of informal education, [www.infed.org/youth work/green_paper.htm] accessed 11 Feb 2020.

Taylor-Robinson, D.; Rougeaux,E.; Harrison D.; Whitehead M.; Barr B; and Pearce A, (2013) The rise of food poverty in the UK British Medical Journal 347: 1756-1833.

The Trussell Trust (2014) Highlights of the Year $2013-2014$, [https://www.trusselltrust.org/wp-content/uploads/sites/2/2015/06/FinancialSummary-2013-2014.pdf] accessed 11 Feb 2020.

The Trussell Trust (2019) End of Year Statistics, [https://www.trusselltrust.org/newsand-blog/latest-stats/end-yearstats/] accessed 14 January 2019.

Trussell Trust (2020) UK Food Banks Report Busiest Month Ever https://www.trusselltrust.org/2020/06/03/food-banks-busiestmonth/\#: : :text=The\%20Trussell\%20Trust\%20reports\%20a,in\%20parcels\%20 given\%20to\%20children\&text=Food\%20banks\%20in\%20the\%20Independent, need\%20for\%20the\%20same\%20period (accessed 10 ${ }^{\text {th }}$ December, 2020)

Tyler, Imogen. 2013. Revolting Subjects. Social Abjection and Resistance in Neoliberal Britain. London: Zed Books.

UNICEF (2020) Southwark families to receive Healthy Breakfast Boxes over Christmas, https://www.schoolfoodmatters.org/news/southwark-families-receivehealthy-breakfast-boxes-over-christmas (accessed 18 ${ }^{\text {th }}$ December, 2020)

Unison (2020) Government U-turn on free summer school meals https://www.unison.org.uk/news/article/2020/06/government-u-turns-freesummer-school-meals/ (accessed $6^{\text {th }}$ August 2020)

United Nations (2019) Visit to the United Kingdom of Great Britain and Northern Ireland Report of the Special Rapporteur on extreme poverty and human rights [https://undocs.org/A/HRC/41/39/Add.1] accessed 6 Feb 2020.

Wheeler, B. (2018) 'Non-prescribed spaces, creativity and narrative formation: a systems-based examination of a community art group exploring food poverty'. Ethnography and Education, 13(3): 359-376.

Wills, W. J. and O'Connell, R. (2018) Children's and Young People's Food Practices in Contexts of Poverty and Inequality, Children and Society 32(3) 169-173.

Dr Jon Ord worked as a youth worker for nearly 20 years, in a variety of settings and has taught youth and community work at UCP Marjon since 2003, where he is now an Associate Professor. He is the author of a number of books and articles on youth work, including the $2^{\text {nd }}$ editon of 'Youth Work Process, Product and Practice'.

Address: Plymouth Marjon University, Plymouth, PL6 8BH, England Email: jord@marjon.ac.uk

Annie Monks has a keen interest in food poverty and volunteered at the local food distribution centre for food banks in Plymouth, she studied at Plymouth Marjon University and worked as a research assistant on this project. 